\title{
Swarthmore College
}

Works

$11-1-2008$

\section{Beauty, Whiteness, And Desire: Media, Consumption, And Embodiment In Egypt}

Farha Ghannam

Swarthmore College, fghanna1@swarthmore.edu

Follow this and additional works at: https://works.swarthmore.edu/fac-soc-anth

Part of the Anthropology Commons

\section{Recommended Citation}

Farha Ghannam. (2008). "Beauty, Whiteness, And Desire: Media, Consumption, And Embodiment In Egypt". International Journal Of Middle East Studies. Volume 40, Issue 4. 544-546.

https://works.swarthmore.edu/fac-soc-anth/39

This work is brought to you for free by Swarthmore College Libraries' Works. It has been accepted for inclusion in Sociology \& Anthropology Faculty Works by an authorized administrator of Works. For more information, please contactmyworks@swarthmore.edu. 


\section{QUICK STUDIES}

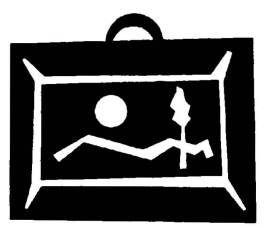

As You SEe IT

Beauty, Whiteness, and Desire: Media, Consumption, and Embodiment in Egypt

FARHA GHANNAM

Department of Sociology and Anthropology, Swarthmore College,

Swarthmore, Pa., USA; e-mail: fghanna1@swarthmore.edu

doi: $10.1017 /$ S0020743808081439

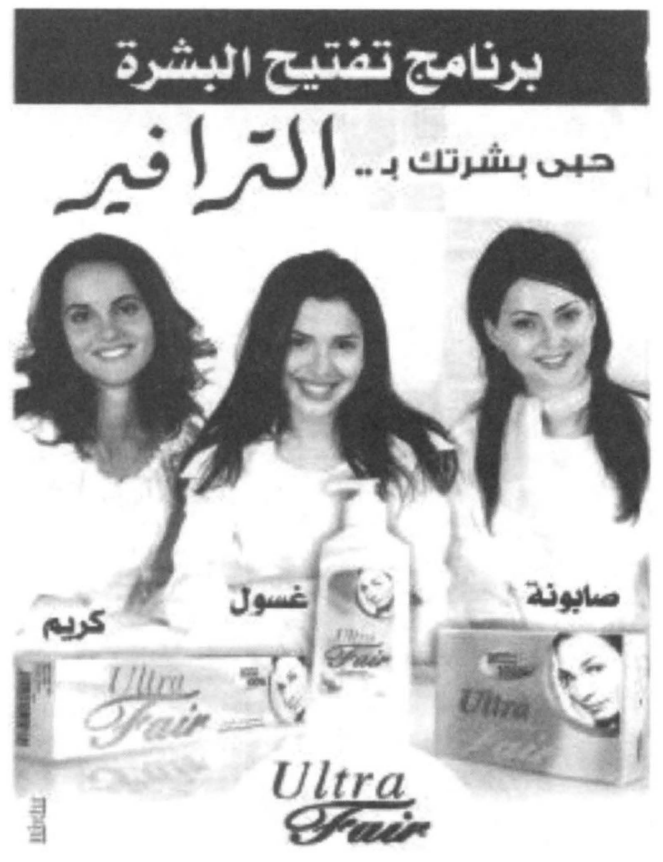

Advertisement for Ultra Fair skin products in Al Shabab magazine. ${ }^{1}$ [A color version of this figure can be viewed online at journals.cambridge.org/mes] 
What is the relationship among gender, embodiment, and consumption? How does the media constitute consumers, desires, and subjectivities? How are we to conceptualize the role of media representations in the making of bodies and selves without granting these representations a deterministic power? These questions were central to my anthropological work on the embodiment of femininities and masculinities in a low-income neighborhood in northern Cairo.

To explore some of these issues, I took a close look at how men and women are depicted in Egyptian daily newspapers and weekly and monthly publications. My aim was to examine the bodily matters addressed and images circulated in advertisements and how they are gendered and engendering. Preliminary content analysis (textual and visual) revealed that most ads related to the body (such as weight loss, makeup, skin treatments, and aesthetic surgery) were mainly geared toward women. The main exceptions were ads that market hair products and creams, pills, herbs, and lotions that promise to enhance sexual performance and abilities. Such ads mainly targeted men and used language and images that strongly identified masculinity with sexual abilities and performances.

Despite their many differences, ads directed to men and women reflect a notion of reflexivity, seen by many scholars as key to the making of bodies and selves in modern times. ${ }^{2}$ Following, monitoring, and changing one's body according to recent trends and fashions become central to the sense of self and how others define the individual. Ads often fragment the body into different parts that can be transformed to meet social expectations and individual desires. These parts can be reshaped, tugged, enlarged, and reduced. The language used in most of these ads makes it the owner's responsibility to utilize the growing number of technologies, products, and procedures to beautify, transform, and improve the body to reflect beauty, desirability, and status. As Sander Gilman describes when discussing aesthetic surgery in the West, it becomes the duty of the individual to find ways to modify the body to secure desirability, eroticism, and happiness. ${ }^{3}$ In Egypt, individuals become responsible for their own happiness, marital happiness, and family harmony, which are all directly linked to the transformation of the body.

These ads often highlight outside brands and products. American, German, British, Indian, Turkish, and Lebanese affiliations are emphasized as signs of distinction. The appeal to the power of the outside, especially the West's power and prestige, becomes clearly linked to masculinity, femininity, beauty, and sexual appeal. In addition to using photos of celebrities like Paris Hilton, ads transliterate English words such as "man," "new look," "spiky," "sexual," and "ultra fair" and insert them in the Arabic writing to further underscore their global connection, sophistication, and effectiveness.

As argued by anthropologists of the media, ads not only reflect social values and norms but also constitute new realities, expectations, subjects, and bodies. ${ }^{4}$ They not only sell a particular product but also introduce new ideas, feelings, and experiences. Thus, an ad about whitening creams (like the one shown on the previous page) is not only selling the lotion but also the idea that whiteness is 
positive, desirable, beautiful, and purchasable. It promises a new possibility for acquiring lighter skin, a preference that is strongly linked to colonial history, regional differences, and class hierarchies. The broad smiles, the English writing, the white clothes, the youthful faces, and the Arabic words directly link the product to important notions such as love, happiness, beauty, and distinction. It is this ability to deploy such notions and closely relate them to local preferences and global images and discourses that is central to understanding the ability of ads to stimulate desires, market products, and shape bodies and identities.

\section{NOTES}

${ }^{1}$ Al Shabab, September 2006, 60.

${ }^{2}$ Anthony Giddens, Modernity and Self-identity: Self and Society in the Late Modern Age (Stanford, Calif.: Stanford University Press, 1991).

${ }^{3}$ Sander Gilman, Making the Body Beautiful: A Cultural History of Aesthetic Surgery (Princeton, N.J.: Princeton University Press, 1998).

${ }^{4}$ Arjun Appadurai, Modernity at Large: Cultural Dimensions of Globalization (Minneapolis, Minn.: University of Minnesota Press, 1996); William Mazzarella, Shoveling Smoke: Advertising and Globalization in Contemporary India (Durham, N.C.: Duke University Press, 2003). 